Synthesis, part of a Special Feature on The Conservation and Restoration of Old Growth in Frequent-fire Forests of the American West

\title{
The Role of Old-growth Forests in Frequent-fire Landscapes
}

\author{
$\underline{\text { Daniel Binkley }}^{1}, \underline{\text { Tom Sisk }}^{2,3}, \underline{\text { Carol Chambers }}^{4}, \underline{\text { Judy Springer }}^{5}$, and William Block $^{6}$
}

\begin{abstract}
Classic ecological concepts and forestry language regarding old growth are not well suited to frequent-fire landscapes. In frequent-fire, old-growth landscapes, there is a symbiotic relationship between the trees, the understory graminoids, and fire that results in a healthy ecosystem. Patches of old growth interspersed with younger growth and open, grassy areas provide a wide variety of habitats for animals, and have a higher level of biodiversity. Fire suppression is detrimental to these forests, and eventually destroys all old growth. The reintroduction of fire into degraded frequent-fire, old-growth forests, accompanied by appropriate thinning, can restore a balance to these ecosystems. Several areas require further research and study: 1) the ability of the understory to respond to restoration treatments, 2) the rate of ecosystem recovery following wildfires whose level of severity is beyond the historic or natural range of variation, 3) the effects of climate change, and 4) the role of the microbial community. In addition, it is important to recognize that much of our knowledge about these old-growth systems comes from a few frequent-fire forest types.
\end{abstract}

Key Words: ecological processes; evolutionary adaptations; historic range of variation (HRV); human values; knowledge gaps; resilience; understory vegetation

\section{INTRODUCTION}

Traditional forestry took decades to understand the unique features of frequent-fire forests. Early foresters in the Southwest were very concerned about the near-absence of young trees in forests dominated by older, widely spaced ponderosa pine (Pinus ponderosa) trees, and they realized that frequent fires prevented the development of closedcanopy, high-wood-producing forests. A young Aldo Leopold (1920) wrote:

...the prevention of light burning during the past 10 years... has brought in growth on large areas where reproduction was hitherto largely lacking. Actual counts show that the 1919 seedling crop runs as high as 100000 per acre. It does not require any very elaborate argument to show that these tiny trees, averaging only 2 inches high, would be completely destroyed by even a light ground fire.
Leopold did not yet have the insight to understand the profound consequences of 100000 seedlings per acre, although he later came to see the more subtle argument that fire prevention thwarted the processes necessary for the long-term health of the forest ecosystem.

Frequent fires challenge the survival of new tree seedlings and strongly shape the long-term development of all the components of a forest. Young trees often establish in clumps, as a legacy of patchy fuels and fire behavior; and this structural legacy may last for centuries. Gaps between clumps may result from a combination of competition with grasses and shrubs, from uneven distribution of seeds, and also the pattern of fire that interacts with the pattern of soils, vegetation, and fine fuels. The intimate mixture of shady clumps of trees and small open meadows provides a local-scale diversity that would be found only at much larger scales in landscapes without frequent fire. Indeed, some classic vocabulary in forestry is not well suited for frequent-fire forests. As noted by Kaufmann et al. 
in this issue, old-growth characteristics in dry, frequent-fire forests are remarkably different from the old-growth images developed in wetter areas. Even the concept of the forest "stand" as a part of a forest landscape with relatively uniform conditions and somewhat distinct boundaries may not be suitable for frequent-fire forests (Long and Smith 2000). The important details about the spatial arrangement of trees in the landscape relate to the clumping of trees into small groups, and to clusters of these groups, rather than to extensive, uniform areas of similar-size trees stretching across hundreds or thousands of hectares (Fig. 1).

The frequent recurrence of fires reinforces a spatial heterogeneity, promoting a forest with high, smallscale variety in plant species composition, animal habitat, and ecological processes. This pattern of local variety is a key defining feature of old-growth forests in frequent-fire landscapes. In this chapter, we consider some of the crucial ecological roles that might depend partially on the spatial arrangements of trees, and those that relate to the fully developed old-growth conditions.

\section{EVOLUTIONARY ADAPTATIONS TO FIRE}

The adaptations of large trees to surviving fire are fundamental in the ecology of old-growth forests in frequent-fire landscapes. Depending on the species, trees in these forests have developed a number of characteristics to withstand and survive fire. Although fire typically kills small conifers with thin bark by overheating or destroying the cambium layer (van Mantgem and Schwartz 2003), most coniferous tree species in the mature state have thick, insulating bark that is relatively nonflammable, long needles, self-pruning lower branches, and deep roots. Giant sequoia (Sequoiadendron giganteum) also experiences rapid growth that raises canopies off the ground quickly, as well as latent buds and serotinous cones (Stephenson 1999). Jeffrey pine (Pinus jeffreyi) develops buds with thick scales that help withstand heat. Sugar pine (Pinus lambertiana) has thick, fire-resistant bark and an open canopy that retards the spread of fire through the canopy. Gray pine (Pinus sabiniana) has thick bark and is self pruning. Arizona pine (Pinus arizonica) has insulated buds, a high capacity to recover from crown scorch and an open crown. Ponderosa pine has thick bud scales; tight needle bunches that enclose and protect the meristems, then open into a loose arrangement that does not favor combustion or propagation of flames; high foliar moisture; and a deep rooting habit. The foliage and buds are also usually elevated away from the flame zone. With its high foliar moisture content, ponderosa pine can withstand extensive scorching as long as the buds and twigs, which tolerate higher temperatures than needles, are not badly scorched.

\section{USING PAST CONDITIONS AS A GUIDE}

Historic range of variability (HRV) or natural range of variability are interchangeable terms along with natural variability, historical variation, and natural range of variability. These terms suggest that past conditions and processes can be used as guidance for managing present-day ecosystems, and that disturbance (and resultant variety) is a vital attribute of nearly every ecosystem (Landres et al. 1999). The HRV approach is just a first step in pondering possible future forests and landscapes, because it is difficult to deduce details about HRV (especially across large areas and long times), and because future climate conditions may not track historical trends. Because of changes in fire regimes, particularly caused by grazing and fire suppression, many frequent-fire forests now function well outside the HRV (see Moore et al. 1999, Veblen et al. 2000, Allen et al. 2002, Arno and Fiedler 2005, Zier and Baker 2006). For example, Sierra Nevada forests currently are undergoing fire-free periods that are much longer than at any time in the past two centuries (Keeley and Stephenson 2000).

\section{Determining the Historic Structure and Function of Old-growth Forests}

Almost all of the frequent-fire landscapes of the western United States have changed dramatically as a result of livestock grazing, timber harvesting, and fire suppression. Given the near absence of fully functioning, old-growth forests in frequent-fire landscapes, scientists have to use a variety of approaches to determine the structure and processes that characterize these forests (Swetnam et al. 1999, Egan and Howell 2001, Friederici 2003). Historical journals, photographs, and records provide information from some forests on the number and sizes of trees before major changes in land use, and the most detailed records even provide information on other features, such as downed logs and bunchgrass locations (Moore et al. 2004). In the absence of historical records, detailed characterizations 
Fig. 1. A cartoon description of the key features of old-growth forests in frequent-fire landscapes (left), in contrast to younger forests lacking fire (right).

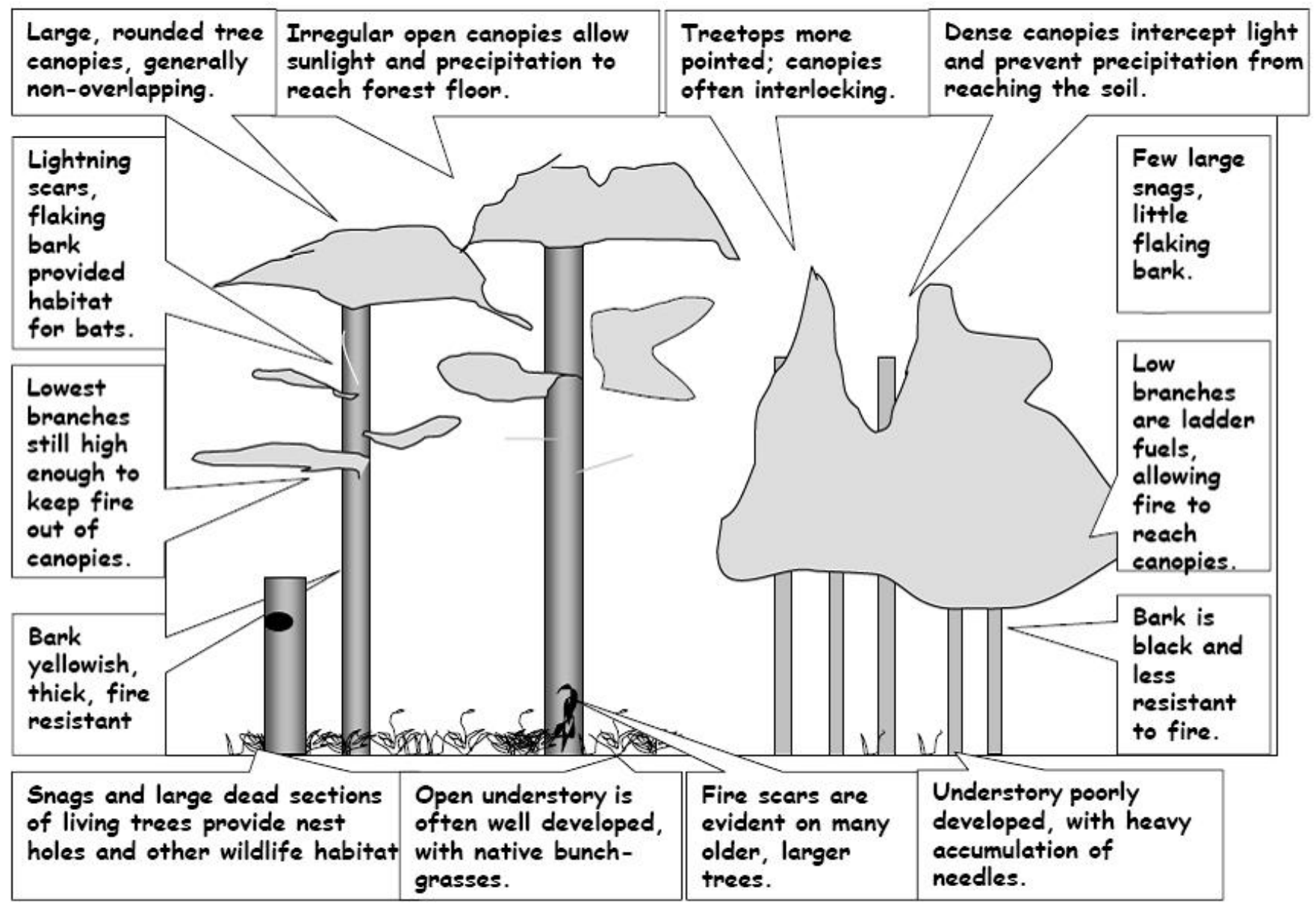

of tree ages, stump ages, and other field evidence can provide solid descriptions of previous conditions. A very few sites, such as the Powell Plateau in the Grand Canyon and some regions of northern Mexico, may have experienced so little change in land use and fire regimes that contemporary measurements are possible (Fulé et al. 2005). Some of the most detailed insights about the structure and function of old-growth forests come from intensive experiments that have reestablished historic forest structure. These treatments include harvesting (and removing) the excessive young trees, retaining most old trees, and reintroducing fire at intervals that match the frequency of historical fires (Bailey and Covington 2002, Fulé et al. 2002, 2006). Forest restoration treatments may not redevelop historical old-growth conditions perfectly for a variety of reasons: 1) the seedbanks of native species may be depleted after decades without fire, 2) exotic species may invade, and 3) the animal communities may not be the same as in past centuries.

We know that historic frequent-fire, old-growth forests were not all alike. For example, Moore and her colleagues (2004), after studying a set of 11 research plots established in the early 1900s in Arizona and New Mexico, found that basal area ranged from 9 to $27 \mathrm{~m}^{2} /$ ha, with an average of 15 $\mathrm{m}^{2} /$ ha. By the end of the century, basal area had doubled on average, although some sites had changed little and others had tripled. Similarly, 
Arno et al. (1995), using dendrochronological reconstructions of six old-growth ponderosaDouglas-fir (Pseudotsuga menziesii) stands in Montana, found basal densities in 1900 ranging from 15 to $35 \mathrm{~m}^{2} /$ ha. The variety of old-growth forest structures probably varied with environmental factors that influence tree establishment, growth, and mortality, including the interacting effects of fires. We also know that the return intervals for fires were longer for most of the ponderosa pine forests in eastern Montana (Morgan et al. 2002) and the Front Range of Colorado-and modestly longer for forests in western Montana (Arno 1980), eastern Oregon (Youngblood et al. 2004), and eastern Washington (Everett et al. 2000) — than for similar forests in Arizona and New Mexico. However, we don't know how this difference in fire regime led to differences in stand structure and function (for example, see Kaufmann et al. 2006)

\section{PROCESSES}

The most essential process in the development of old-growth conditions is time. Frequent-fire forests occur under relatively dry conditions, and the lack of abundant water limits the growth rates of trees. Forests with slow-growing trees take 100-200 years to begin to show the full spectrum of old-growth structure and processes.

However, time alone is not sufficient to encourage old growth in frequent-fire forests. Fundamental to the development of old-growth conditions is the interaction of forest processes with repeated fires. In the absence of repeated fire, tree density tends to remain high, and the fuel structure develops to the point where a very intense fire kills most of the trees. As a result, old-growth conditions are never reached.

Frequent surface fires allow larger trees to persist, limit the success of new trees, and foster the spatial pattern of open meadows mixed with tree clumps. Surface fires that recur every few years or decades kill most of the small trees that managed to establish during years with favorable precipitation and seed crops. The trees that survive the fires experience less competition for light and soil moisture, leading to higher rates of individual growth, thicker bark, and higher canopy base heights - all of which makes these trees more resistant to subsequent surface fires. The grasses, forbs, and shrubs that thrive between clumps of trees are typically burned by surface fires, but these plants often resprout from surviving roots or reseed.

Without the recurring cultivation of the forest by fire, old-growth conditions may not develop. Fire suppression allows tree seedlings to recruit in large numbers, forming denser stands. Wildfire spreads more easily into the canopies of smaller trees with low branches, and from smaller trees into the crowns of previously fire-resistant old trees. With abundant small trees established among the more scattered old growth, fire may spread rapidly across large areas, with high mortality in all age and size classes.

\section{Productivity, Hydrology, and Nutrient Cycling}

One of the most distinctive features of frequent-fire, old-growth forests is the major contribution that the understory vegetation (grasses, forbs, shrubs) makes to ecosystem diversity and productivity. In the absence of fire, the density of overstory trees increases, which reduces the diversity of understory vegetation 10-30\% (Fig. 2, Laughlin and Grace 2006). This relationship between the density of trees and understory diversity is further influenced by the number of years between fires (the fire return interval). For example, a ponderosa pine forest on the Kaibab Plateau that burned in the past 10 years might have 35 species in the understory,

compared with 28 species after 70 years without a fire, and 22 species after 120 years without a fire (Laughlin et al. 2005).

Restoration treatments reduce tree density and lower the total growth of trees in a forest, but increase the growth of residual (retained) trees and the biomass and productivity of the understory. In Montana, understory plant diversity declined the first year after a thinning and burning restoration treatment in a ponderosa pine-Douglas-fir forest, but increased significantly 2 years after treatment (Metlen and Fiedler 2006). Experiments around northern Arizona typically show understory biomass and growth increases of more than two-fold in response to thinning and prescribed burning (Fig. 3; Abella 2004, Gildar et al. 2004, Moore et al. 2004). Restoration treatments appear to have little effect on the total productivity of the forests, but they shift how the growth is allocated between the overstory and understory. A restoration experiment at Fort Valley near Flagstaff, Arizona showed that total production did not change, but the proportion accounted for by the understory rose from $10 \%$ to 
Fig. 2. The richness of understory plant species declines with increasing density of overstory pine trees, on the Kaibab Plateau in northern Arizona (after Laughlin and Grace 2006). Typical historic conditions would have had about 35 species per 0.1-ha plot, but with changing land use and fire regimes, the most common species richness has declined to 25 to 30 species per 0.1 -ha plot.

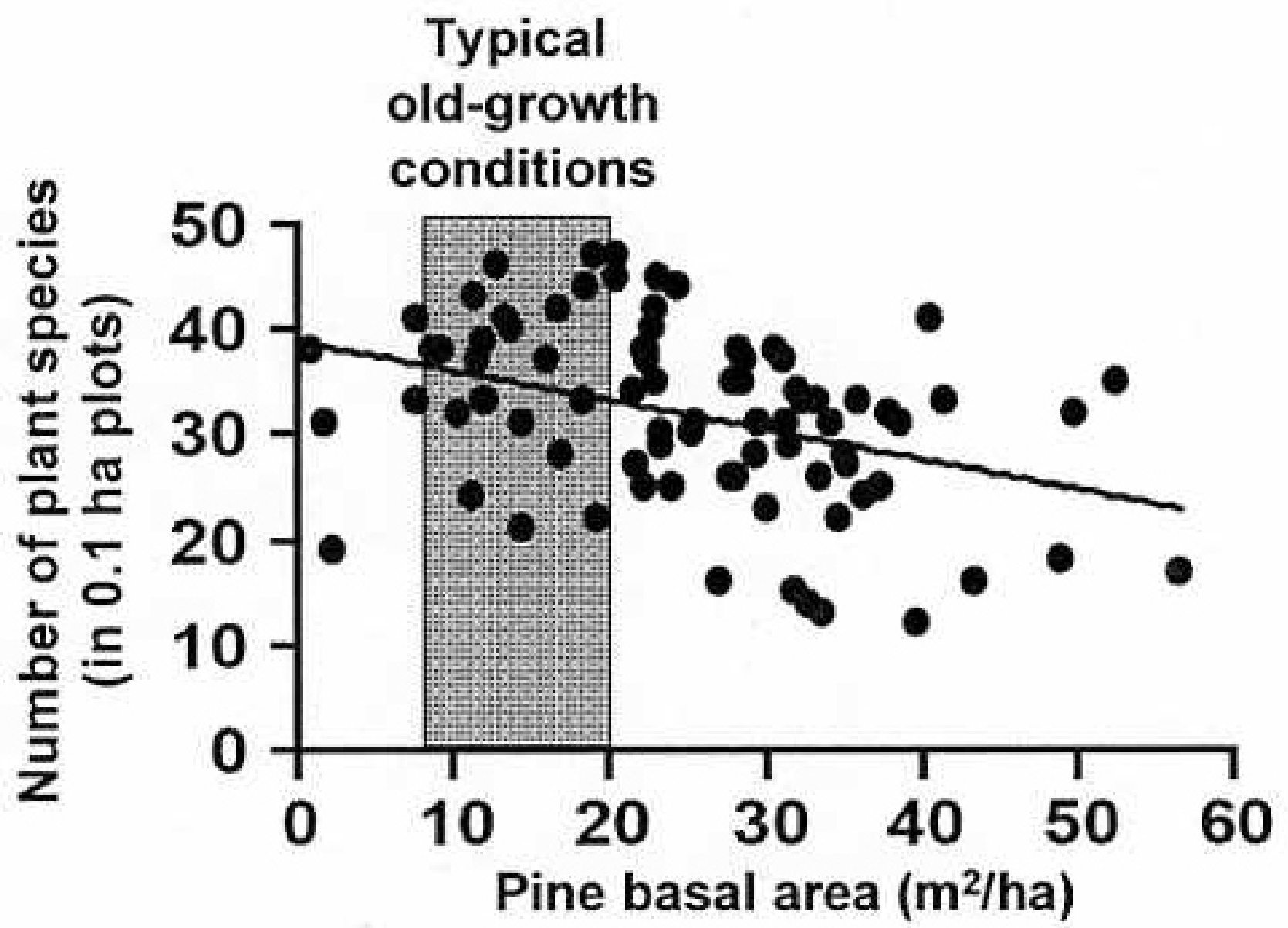

about $25 \%$. The benefit of restoration treatments also differs among plant types. For example, the restoration responses at Fort Valley were greater for grasses than forbs (Moore et al. 2006), greater for leguminous forbs than other types, and greater for $\mathrm{C}_{3}$ grasses (e.g., bottlebrush squirreltail (Elymus elymoides subsp. elymoides)) than $\mathrm{C}_{4}$ grasses (e.g., mountain muhly (Muhlenbergia montana)). All of these trends might differ in response to major or minor differences in restoration prescriptions, site history, and current weather.
The higher productivity of understory plants in oldgrowth (and restored) forests in frequent-fire landscapes results in part from the low canopy leaf area of the overstory trees. Tree canopies cover less than half of the ground area (and commonly as little as $25 \%$ ). Despite this patchy distribution of trees, the total amount of leaves in the tree canopy on 1 ha would still provide 2 or 3 ha of leaf surface area to intercept light. Forests in landscapes with higher supplies of water commonly have canopy surface areas of 4 to 6 ha displayed for each hectare of ground area. 
Fig. 3. Understory biomass and growth were much higher in forests with restoration treatments than in control forests (from summary of Abella 2004, Gildar et al. 2004, Moore et al. 2006). The greatest proportional increases occur when the biomass in the unrestored forests is particularly low.

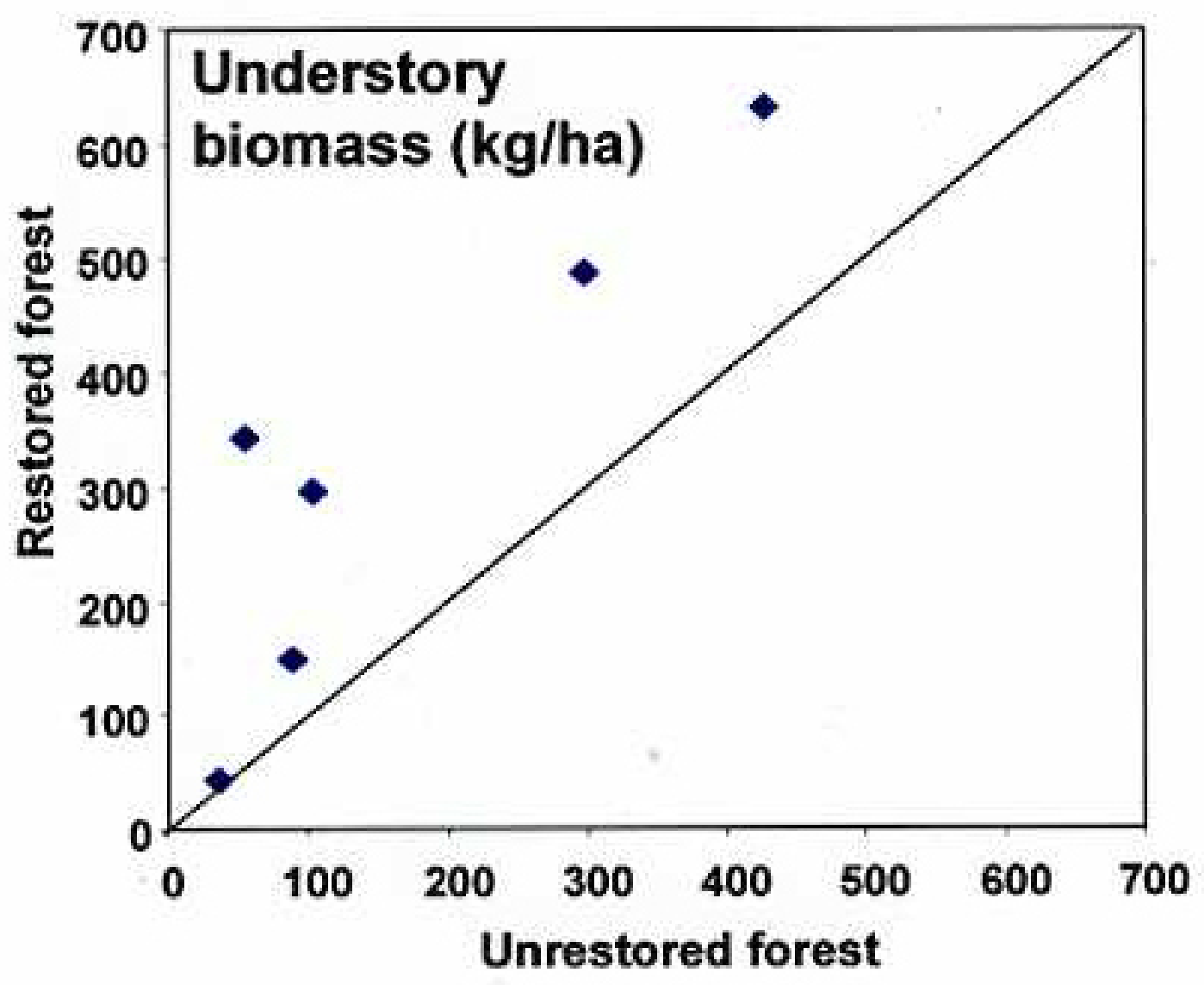

The amount of tree leaf area in a forest may have important effects on the supply of water in the soil that is available for both trees and understory vegetation. Precipitation falling on tree canopies may be intercepted, accumulating briefly on the needles before evaporating back to the atmosphere, never reaching the soil. Forests with high leaf area not only lose more precipitation from this interception loss, but they also have higher rates of water use by trees, with lower amounts of soil water available for use by understory plants. In wetter landscapes, changes in the amount of tree leaf area influence the amount of water reaching streams. For example, reducing tree cover in higher-elevation forests in the Rocky Mountains commonly increases stream flow by 15 to $30 \%$ (MacDonald and Stednick 2003). The amount of water flowing in streams in frequent-fire landscapes depends less on the density and size of trees (and canopies) than in wetter areas, because drier conditions mean that water not used by trees will be used by understory plants. Restoring old-growth structure to forests in frequent-fire landscapes may lead to increased streamflow during wet periods and, perhaps, to some recharge of subsurface aquifers.

Forest restoration treatments generally improve the water status of large trees, reducing water stress, and increasing the volume of resin in stems (Wallin et al. 2004, Zausen et al. 2005). Improved water 
status may enhance the overall vigor of trees, leading to lower rates of mortality from bark beetles and other insects and diseases.

Nutrient cycles in forests are influenced directly by fire, including losses (such as nitrogen converted to gas as biomass is consumed) and probably shortterm increases in availability of some nutrients (including nitrogen). In the longer run, differences between old-growth and non-old-growth conditions may derive from the indirect effects of changes in vegetation composition than from the direct, cumulative effects of fires (Hart et al. 2005a).

\section{EVOLUTION AND ADAPTATION}

The biotic processes in forests develop from interactions between genes, organisms, and environmental factors. The genetics of a forest include those of trees, understory plants, wildlife, and the unimaginably diverse organisms in the soil. Although the interactions among genes, organisms, and environmental factors in a ponderosa pine forest are beyond the scope of this article (and indeed, beyond human comprehension!), we provide a few examples to illustrate the complexity and resilience of this system.

\section{Bark Beetles}

Bark beetles are an important, natural component of many conifer ecosystems. Bark beetles (and their fungal symbionts) routinely kill small numbers of pine trees and, occasionally, extremely high beetle populations lead to massive pine mortality across very large areas. A number of factors-drought, lightning strikes, root pathogens, large fire scars, severe defoliation, tree senescence, excessive competition-make an individual old tree or stand more susceptible to bark beetle outbreaks. Recent thinning may also contribute to increased wind turbulence in a stand, leading to root damage and, perhaps, making individual trees susceptible to attack (Christiansen et al. 1987).

Coniferous trees have developed two main mechanisms to counter beetle attacks. First, they have a system of resin ducts in the phloem and xylem that can pitch-out invading beetles. Second, they have developed a hypersensitive reaction to invasion by microorganisms (including fungi, bacteria, and viruses) that enter the tree along with the beetles. A necrotic area, impregnated with resinous and phenolic compounds that prevent beetle gallery construction and fungal proliferation, then forms around the point of infection. This wound resin is highly toxic to beetle eggs and larvae and also inhibits fungal growth (Christiansen et al. 1987).

The ability of a large, old tree to resist an attack depends on its genetic makeup and physiological status (Franceschi et al. 2005). Independent of age, ponderosa pine trees grow slowly when stressed by competition. However, because most old trees are large in size and stature, they may have higher maintenance respiration demands because of the amount of living, non-photosynthetic tissue they maintain compared with younger trees (Skov et al. 2004). Another factor that may limit photosynthetic rate is that these large trees also tend to have more branch junctions and a longer root-leaf hydraulic path length that may decrease hydraulic conductance (Skov et al. 2004). Together, these factors may all contribute to slow growth of old ponderosa pine trees.

Bark beetles are only one of many potential threats to ponderosa pine trees, and the susceptibility to each threat differs among trees. For example, ponderosa pine trees may be attacked by bark beetles and infected by dwarf mistletoe (Arceuthobium spp.), but the success of each of these varies among individual ponderosa pines (Fig. 4). Trees that appear susceptible to beetles appear to be resistant to dwarf mistletoe, and vice versa. The continued survival, growth, and seed production of individual pine trees may depend in part on the local prevalence of parasites, which depends in turn on the local genotypes of pines and local environmental conditions.

\section{Abert's Squirrels}

Abert's squirrels (Sciurus aberti) are also highly dependent on ponderosa pine trees. Ponderosa pines provide them with places to live, nest, rest, and hide from predators as well as food in the form of bark, buds, flowers, and seeds (Hoffmeister 1986). Squirrels choose individual trees based on the (heritable) chemistry of tree phloem. As a result, different populations of Abert's squirrels are adapted to different populations of ponderosa pine (Snyder 1992, 1993; Snyder and Linhart 1994). 
Fig. 4. Some ponderosa pine trees were heavily attacked by bark beetles, some heavily infected by dwarf mistletoe parasites, and some were unaffected - but no trees were heavily attacked by both bark beetles and dwarf mistletoe (after Linhart et al. 1994).

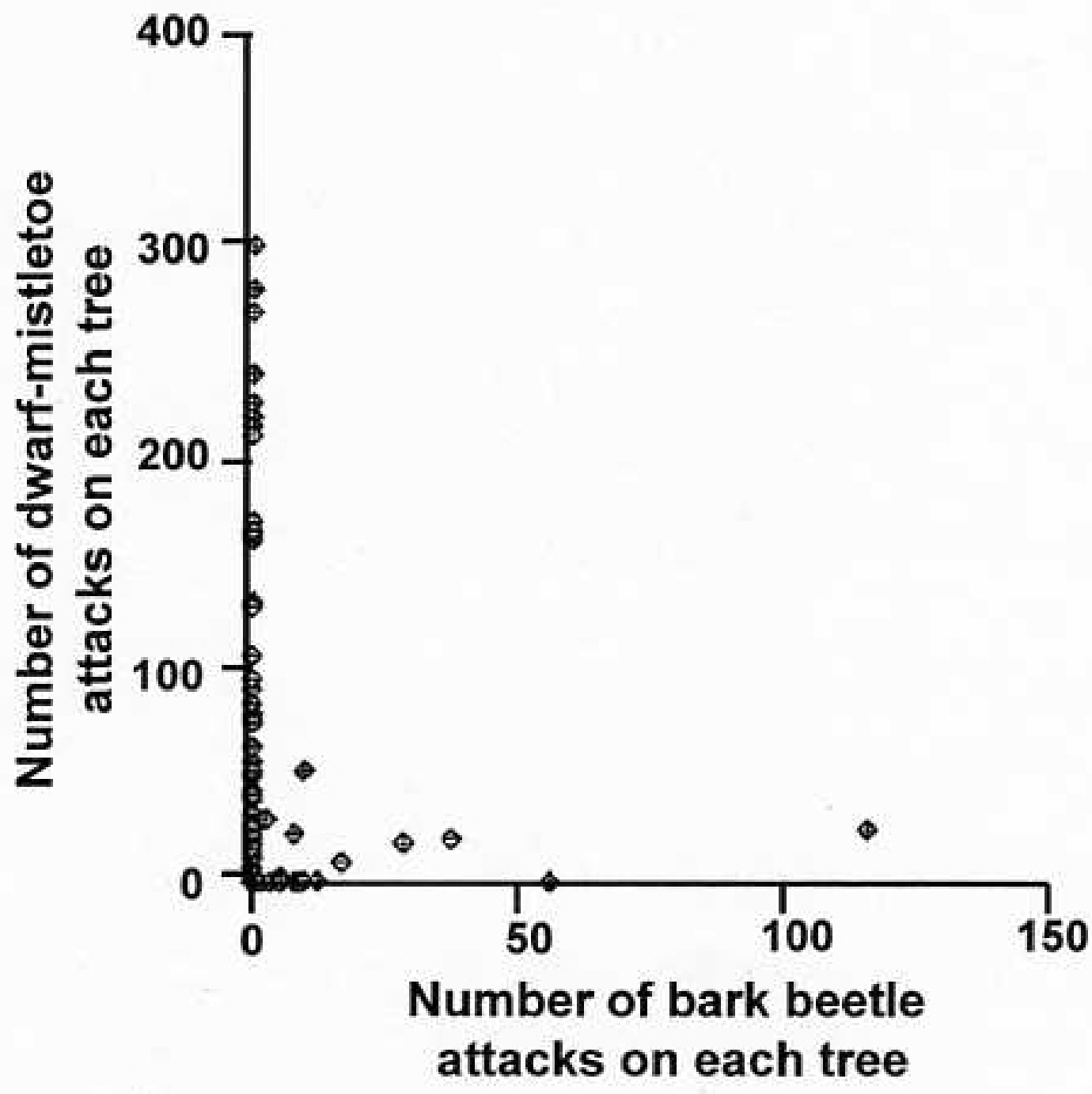

Yet another ecological interaction connects ponderosa pines and Abert's squirrels. Squirrels eat mycorrhizal fungi and help disperse it through their fecal pellets. Mycorrhizal fungi are very important to plant productivity, so if the fungi were rare, then squirrels could, perhaps, enhance forest productivity (Vireday 1982, Kotter and Farentinos 1984a, b).
Mooney and Linhart (2006) have recently developed an even more interwoven story about pines, growth, birds, ants, spiders, aphids, wasps, and dwarf mistletoe. 


\section{Genetics and Old Trees}

The genotypes of pine trees are influenced by both selective pressures (Abert's squirrels, beetles, and dwarf mistletoes), and by the flow of genes in the neighborhood. The genes of paternal trees flood the local landscape as pollen drifts on the wind, but maternal genes disperse only as far as seeds can fall from a tree or be carried by animals (Latta et al. 1998). Old trees may be particularly important in a forest, as they have (by definition) survived centuries of changing environmental and biotic challenges. The presence of these trees in a landscape is critical for contributing both seeds and pollen to later generations of trees.

\section{Resilience and Fire at the Landscape Scale}

Just as individual trees have mechanisms that make them resistant to bark beetles and fire, a healthy, functioning forest will exhibit resilience on a large scale. Persistence, resilience, and resistance are all terms applied to the stability of an ecosystem (Holling 1973, Gunderson et al. 1995, Gunderson and Holling 2002). Ecosystem fragility is the opposite of stability and is expediently defined as "...the degree of change in species abundances and in species composition, following disturbance" (Nilsson and Grelsson 1995). Frequent-fire forests are highly stable in the long term, as long as fire is maintained in the system. However, they may be considered fragile in the short term following a fire. Moreover, many of these forests are now considered fragile in the long term, particularly following the catastrophic fires that result from long periods of fire suppression.

\section{OLD-GROWTH FOREST COMPOSITION}

Although processes are the driving forces behind any ecosystem, those processes are reflected and supported by the composition of the ecosystem, that is by the living and non-living entities that exist in the ecosystem. Old-growth forests, by definition, have old trees, but the presence of old trees is just the beginning of a description of the composition of an old-growth forest. The frequent return of fires provides the opportunity for a great range of plants, animals, and microbes to coexist in the same landscape.

\section{Plant Composition and Structure}

In frequent-fire landscapes, the diversity of plant species in the forest understory is much greater than the diversity of overstory species. Moreover, frequent fires strongly influence the composition of understory plant communities. The most striking feature of old-growth patches of ponderosa pine may be the towering "yellow-bellies"- the largediameter giants with the yellowish, fire-resistant bark. However, these forests are characterized as much by the understory that develops in the diverse range of habitat conditions: near clumps of big trees, in small openings between clumps, and in the open meadows between groups of large trees. Native perennial graminoids, including several species of fescue (Festuca spp.) and sedges (Carex spp.), dropseed (Blepharoneuron tricholepsis, Sporobolus spp.), Indian ricegrass (Oryzopsis spp.), and galleta (Pleuraphis spp.), as well as grazing-tolerant squirreltail and western wheatgrass (Pascopyrum smithii) and the ubiquitous grama grasses (Bouteloua spp.), form diverse understory communities that account for a large portion (more than half) of the net annual primary production in many old-growth ponderosa pine stands (Moore et al. 2004).

In addition to the native grasses, many annual and perennial forbs occur, usually as subdominants or rare components of the understory plant community. Native penstemon (Penstemon spp.), evening primrose (Oenothera spp.), and lowgrowing sages (Artemesia spp.) are complemented by diverse composites that flower throughout the growing season. Fire-resilient or -adapted shrubs, such as kinnikinnick (Arctostaphylos uva-ursi) and serviceberry (Amelanchier spp.) in the Inland Northwest, and cliffrose (Purshia spp.) and ceanothus in the Southwest, are characteristic of open-growing, old-growth pine forests. In many Southwest locations, Gambel oak (Quercus gambelii), which can be found from a low-growing shrub to subdominant tree, is the second most abundant woody plant.

This heterogeneity in species composition and structural types is characteristic of most types of old-growth forests that develop in frequent-fire landscapes. Large overstory trees typically occur in scattered clumps of several to several dozen individuals sometimes in a dense matrix of younger trees, and other times intermixed with grassland openings of several acres. In terms of species 
composition, structural diversity, and ecological function, such old-growth forests contrast sharply with the dense stands that commonly develop when fires are suppressed. For example, Gambel oak and ceanothus are common shrubs in most Southwest ponderosa pine forests, but they typically are more common, and individual plants are larger and more developed, in open forests dominated by large pines. This diversity in the woody plant community has far-reaching implications, in part because these species support insect communities that are more diverse and abundant than those found in pure stands of ponderosa pine. Insect abundance, in turn, influences bird and bat populations, pollination rates, and the amount of wildlife forage. In this way, the composition and structural attributes of the ponderosa pine trees set the template for a potentially diverse plant community whose composition and function vary widely.

\section{Animal Communities}

Wildlife species respond in a host of ways to the structure of forests, and to boundaries between forests with different structures. Old-growth forests provide habitat for many wildlife species, but the critical habitat characteristics vary tremendously among species in both time and space. Some species are year-round residents, and others use old-growth forests only for breeding, wintering, or migration. Similarly, some species (e.g., pygmy nuthatch (Sitta pygmaea)) rely on specific old-growth structural components, such as large trees, whereas others (e. g., Abert's squirrel) need the structure of a whole patch of old-growth trees to facilitate their movements and provide food. Some species (e.g., northern goshawk (Accipiter gentilis)) require oldgrowth forest conditions within an entire landscape matrix that contains non-old-growth forests to meet all their ecological needs.

Starting at the small end of the scale, standing dead trees (snags) and partially dead trees (living snags) are an important part of a living forest ecosystem (Waskiewicz 2003, Chambers and Mast 2005). Dozens of species of birds and bats rely on living and dead trees for habitat, and many of these species in turn may influence the success (or failure) of other organisms (e.g., defoliating caterpillars). Resource managers are commonly required to provide a minimum number of snags, but more recent insights have indicated snags alone may not be the key to providing habitat for species such as bats, nuthatches, and bluebirds because the longevity and number of dead snags is limited in frequent-fire forest. For instance, Saab et al. (2006) tested prescribed fire on more than 130 plots in the southwestern United States, and found an average loss of $35 \%$ of the downed wood and half of the standing snags (Saab et al. 2006). Boucher et al. (2000) pointed out that snags may not last long in frequent-fire forests because surface fires either ignite snags or topple them by burning the roots. The best long-term habitat may be provided by living snags, which are live trees with large dead limbs or tops. These living snags often develop after lightning strikes, beetle infestations, pathogen attack, or a combination of these factors.

Moving up to the scale of patches or stands, forest structure influences survival and population persistence of a variety of wildlife species. Very uniform spacing of trees, which is the typical result of traditional silvicultural thinning treatments, degrades habitats for Abert's squirrels (Dodd et al. 2003). Information on characteristics and sizes of patches needed by the squirrel and the spatial arrangement of these patches are necessary parts of silvicultural prescriptions that ensure viable populations of these squirrels. Similar silvicultural and management decisions are required for other old-growth-dependent species, including spotted owls (Strix occidentalis).

At the scale of entire landscapes, old-growth forests will likely be part of a landscape mosaic that includes forests that lack old-growth characteristics. These non-old-growth habitats (ranging from meadows to dense young stands to maturing secondgrowth stands) might support some aspect of an animal species' needs. For example, northern goshawks are habitat generalists and their populations are often limited by the availability of food, which causes them to move between different habitat types. Reynolds et al. (1992) developed a landscape model of goshawk habitat that identifies a landscape-scale mosaic of six vegetation structural stages, which provide habitat for a suite of northern goshawk prey species. These vegetation structural stages range from grass-forb regeneration conditions to old-growth forest. Although northern goshawks need old-growth forests, particularly for nesting, they also benefit from a diverse mosaic across the landscape.

There are also symbiotic, co-evoluntionary relationships that animals have throughout old- 
growth forests. As noted in the discussion above about Abert's squirrels, there is almost no limit to the nature of interactions in forests, and we are far from having a clear understanding of which interactions have major, cascading effects. Some wildlife species are considered keystone species in that other species depend on them to provide necessary conditions. For example, populations of hairy woodpeckers (Picoides villosus) increase after fire, just as populations of beetles increase (CovertBratland et al. 2006). In ponderosa pine forests in the Southwest, half of the species that nest in tree cavities cannot excavate cavities (secondary cavitynesting species), so hairy woodpeckers may be critical in supporting a diversity of animals. The feedback cycle turns yet again because, without fires, the population of hairy woodpeckers may be low, reducing the habitat opportunities for other species, further changing the complex forest ecosystem.

Management activities that move a forest away from old-growth conditions change the opportunities for many species. For example, Szaro and Balda (1979) compared four treatments with an uncut control plot that had some characteristics of old-growth forests. Pygmy nuthatches, red-faced warblers (Cardellina rubrifrons), hermit thrushes (Catharus guttatus), cordilleran flycatchers (Empidonax occidentalis), and violet-green swallows (Tachycineta thalassina) lost habitat with treatments that moved the forests away from old-growth forest conditions.

Grazing alters herbaceous plant composition and structure, affecting habitat for species such as Mogollon voles (Microtus mogollonensis) (Chambers and Doucett 2008). Using a stable-isotope approach, these scientists found that herbivorous voles rely on grass and herbs for food, and that $\mathrm{C}_{3}$ plants (e.g., yarrow (Achillea millefolium), lupine (Lupinus spp.), fescue, mulleins (Verbascum spp.), snakeweed (Gutierrezia spp.)) were a more important food source than $\mathrm{C}_{4}$ plants (e.g., species of muhly (Muhlenbergia spp.) and grama grasses). Excessive ungulate grazing and introduction of invasive plant species that lead to changes in plant species composition or reductions in $\mathrm{C}_{3}$ plants in montane grasslands and forests would reduce habitat quality for Mogollon voles. Mogollon voles are also important food for the threatened Mexican spotted owl (Strix occidentalis lucida) (Ward 2001). Recent research indicates that vole populations are reduced in pine-oak forests as the result of past logging and grazing practices (Block et al. 2005).
As noted throughout this special issue, the loss of old-growth structure in frequent-fire landscapes commonly leads to uncharacteristically severe wildfires, which, in turn, benefit some animal species and harm others. Bock and Block (2005), for instance, compared the bird communities in unburned and moderately and severely burned forests. Three years after the fires, the unburned forest had 31 species in the breeding season and 26 in the non-breeding season. Both levels of burn intensity increased the diversity of birds, with more than 40 species of breeding birds and 33 species of non-breeders. Species groups that increased in response to fire included woodpeckers, flycatchers, and thrushes.

Restoration treatments that move forests toward old-growth structure and composition appear to be effective in restoring bird habitat. Germaine and Germaine (2002) found that the fledgling rate (i.e., number of young to leave the nest) for western bluebirds (Sialia mexicana) in restored stands was 1.6 times greater than in dense, untreated stands. Converse et al. (2006a, b) evaluated effects of fuelreduction treatments on small mammals and found that total biomass and population sizes of small mammals generally increased following thinning and fire. The most thorough assessments of postrestoration animal responses come from landscapescale treatments near Mt. Trumball in the Grand Canyon-Parashant National Monument in northern Arizona (Covington et al. 2005). Various aspects of wildlife habitat and populations were examined for up to 9 years, and demonstrated that restoring oldgrowth forest structure generally favored species or had much lower negative effects than standreplacing fire. Mule deer (Odocoileus hemionus) tended to use restored portions of the landscape at night, although they used restored and control areas about equally during the day. Abert's squirrel populations declined in response to the lower density of pine trees, but the squirrels did continue living in trees in the restored areas. Breeding pairs of northern goshawks were found in control and restored areas, and fledglings were successful in both forest types. The densities of butterflies doubled in restored areas.

\section{Microbial Communities}

Given that microbial interactions and processes are the foundation of much of the forest ecosystem, surprisingly little is known about the differences in 
microbial communities between old-growth forests and post-fire-cessation forests. The two microbial communities that we know the most about are wooddecaying fungi and mycorrhizal fungi.

A number of wood-decaying fungi infect primarily old trees, roots, and large branches. Several species of wood-decaying fungi found in unmanaged older forests are rare in younger stands (Romme et al. 1992). Aging trees tend to become increasingly vulnerable to wood-decaying fungi because fungi can enter through dead branch stubs, knots, broken tops, fire scars, and wounds such as those caused by bark beetles or woodpeckers (Farris et al. 2004). In addition to the vital role these pathogens play in the carbon cycle and in recycling nutrients for plants, they also create valuable habitat for numerous wildlife species (Marcot 2002).

Mycorrhizal fungi form symbiotic associations with tree roots, providing water and nutrients to roots in exchange for sugar. Experiments by various researchers have shown that fire may substantially affect these fungal associations, particularly near the soil surface. For example, a study by Pattinson et al. (1999) that simulated the effect of fire showed a decline in numbers of mycorrhizal propagules and a reduction in the hyphal network (the tiny, networked strands of fungus). Korb et al. (2003) found a rapid increase in arbuscular mycorrhizae following restoration treatments in northern Arizona, whereas Smith et al. (2005) reported a short-term reduction in ectomycorrhizal fungi (EMF) following prescribed fire in Oregon.

Researchers have also studied the effects of seasonal burning on the mycorrhizal community. Smith et al. (2004) detected that fall burning in dry ponderosa pine stands significantly reduced duff depth, live root biomass, and EMF species richness compared with spring burning. The probability of mature tree mortality was also greater after fall burning. Meyer et al. (2005) found that burning reduced litter depth and log volume as well as the frequency, biomass, and species richness of mycorrhizal truffles in an area of the Sierra Nevada. The authors posit that decaying woody debris forms an important reservoir of moisture and nutrients, especially in dry forests, for fruiting fungi. It also appears that mycorrhizal fungi are more likely to survive when the duff layer is thin or moist.

Hart et al. (2005a) report that repeated burning (every 2 years during a 20 -year period) reduced fine root length, fine root biomass, and mycorrhizal root biomass, as well as the amount of nitrogen and phosphorous stored in the belowground pools. The authors speculate that the change in these pools most likely occurred during the first few prescribed burns when the fuel loads and fire intensities would have been highest. Their results suggest that such frequent burning may have negative long-term effects on belowground biomass pools and nutrient cycling. They also postulate that these negative effects may be avoided by mechanically removing some of the accumulated fuel before prescribed burning.

Despite these descriptive studies and experiments, we essentially know very little about the critical changes that may (or may not) follow the loss of old-growth characteristics in a forest. A recent study (Hart et al. 2005b) found that a fire following a long, fire-free period reduced the diversity of the bacterial community by more than half, yet more than doubled the diversity of the fungal community. We do not know if these dramatic changes have important cascading effects in the forest.

\section{HUMAN VALUES}

Although this is covered in more depth by other authors in this special issue, we also want to say that old-growth forests in frequent-fire landscapes provide a host of human values that go beyond the list of species present, or economic and ecological functions. For instance, old-growth forests carry a legacy of information from earlier times. They can tell us a great deal about how climates have varied in past epochs, and how the forests (and fires) responded. Without the information held in tree rings, we would not know how the landscapes of the southwestern United States were influenced by patterns of El Niño/Southern Oscillation precipitation (Grissino-Mayer and Swetnam 2000) or to what degree the rise and fall of dryland civilizations related (or not) to climate (Dean 1988). We also recognize that many people see an inherent beauty in old-growth forests (Huckaby et al. 2003), and find personal sustenance from these "wilderness" or wild landscapes. 


\section{KNOWLEDGE GAPS}

All forests are complicated ecosystems, making the potential list of gaps in our knowledge almost unbounded. Nevertheless, we can identify several key areas where studies and experiments are needed to fill major gaps that hinder restoration efforts of old growth in the frequent-fire forests of the American West.

\section{Ability of Understory Vegetation to Respond to Restoration Treatments}

How well can we recover the historical understory (and related animal habitat features) that characterized old-growth conditions? The absence of fire for a century has been coupled in many forests with a host of other land-use impacts, including intensive livestock grazing and logging. Long-term plots from northern Arizona have shown not only declines in total understory production and species diversity, but also shifts among vegetation types (such as greater losses of $\mathrm{C}_{4}$ grasses than $\mathrm{C}_{3}$ grasses). How well can the understory recover its former productivity and species composition in response to thinning or thinning plus fire? Does the season and/ or frequency of burning have an effect on the understory? Will adding native seed from nearby areas be critical? How did use by Native Americans affect the understory of pre-European-settlement, old-growth forest understories? More experiments across a variety of landscape conditions are needed to answer these and other questions related to understory vegetation.

\section{Ability of Frequent-fire Forests to Recover Following Catastrophic Wildfires}

How does ecosystem recovery progress after severe wildfires that exceed the historical range of fire behavior in frequent-fire landscapes? We expect that recovery will be slow, but will recovery eventually occur or will the forests be converted to other vegetation types (grasslands or shrublands)? What restoration treatments would be most effective for recovering natural forest composition, structure, and function after large, severe fires? Which treatments can move forests toward old-growth conditions and also reduce risks of severe fires?

\section{Ability to Extrapolate Knowledge of Certain Forests to Other Places and Forest Types}

Much of our knowledge about old-growth conditions in frequent-fire landscapes comes from a very limited range of forest types, and detailed information comes from an even more restricted set of intensive study sites. How representative are the ponderosa pine landscapes of northern Arizona for ponderosa pine in other areas? How different are dry mixed-conifer forests from ponderosa pine forests, and how do they vary with landscape position locally and throughout the West? We have a good general understanding the key questions and the important processes, but restoration of oldgrowth conditions in any local forest will depend on locally appropriate details.

\section{The Uncertainty of Climate Change and its Effects on Forested Ecosystems}

Climates have changed dramatically in the past 10 000 years, and the $21^{\text {st }}$ century will likely differ from the $19^{\text {th }}$ century. What do we need to know to foster old-growth forest conditions under various climate scenarios? If managers can only afford to restore a portion of a landscape (which is almost always the case), should restoration focus on lower-elevation sites (with the risk that climate changes would shift the ecotone upward)? This knowledge gap will probably not be filled by data collection or experimentation, but the potential effects of climate change need to be kept in mind.

Responses to this article can be read online at:

http://www.ecologyandsociety.org/vol12/iss2/art18/responses/

\section{LITERATURE CITED}

Abella, S. R. 2004. Tree thinning and prescribed burning effects on ground flora in Arizona ponderosa pine forests: a review. Journal of the Arizona-Nevada Academy of Science 36:68-76.

Allen, C. D., M. Savage, D.A. Falk, K. F. Suckling, T. W. Swetnam, T. Schulke, P. B. Stacey, P. Morgan, M. Hoffman, and J. T. Klingel. 2002. Ecological restoration of southwestern ponderosa pine ecosystems: a broad perspective. Ecological Applications 12:1418-1433. 
Arno, S. F. 1980. Forest fire history in the northern Rockies. Journal of Forestry 78:460-465.

Arno, S. F., and C. E. Fiedler. 2005. Mimicking nature's fire: restoring fire-prone forests in the West. Island Press, Washington, D.C., USA.

Arno, S. F., J. Scott, and M. Hartwell. 1995. Ageclass structure of old growth ponderosa pinel Douglas-fir stands and its relationship to fire history. U.S. Forest Service Research Paper 481.

Bailey, J. D., and W. W. Covington. 2002. Evaluating ponderosa pine regeneration rates following ecological restoration treatments in northern Arizona, USA. Forest Ecology and Management 155:271-278.

Block, W. M., J. L. Ganey, P. E. Scott, and R. King. 2005. Prey ecology of Mexican spotted owls in pine-oak forests of northern Arizona. Journal of Wildlife Management 69:618-629.

Bock, C. E., and W. M. Block. 2005. Response of birds to fire in the American southwest. Pages 10931099 in C. J. Ralph and T. D. Rich, editors. Bird conservation implementation and integration in the Americas: Proceedings of the third international Partners in Flight conference. Volume 2. U.S. Forest Service General Technical Report PSW-GTR-191.

Boucher, P. F., W. M. Block, G. V. Benavidez, and L. W. Wiebe. 2000. Implementing the expanded prescribed fire program on the Gila National Forest, New Mexico: implications for snag management. Proceedings of the Tall Timbers Fire Ecology Conference 21:104-113.

Chambers, C. L., and R. R. Doucett. 2008. Diet of the Mogollon vole as indicated by stable isotope analysis (13 C and $15 \mathrm{~N}$ ). Western North American Naturalist (In press).

Chambers, C. L., and J. N. Mast. 2005. Ponderosa pine snag dynamics and cavity excavation following wildfire in northern Arizona. Forest Ecology and Management 216:227-240.

Christiansen, E., R. H. Waring, and A. A. Berryman. 1987. Resistance of conifers to bark beetle attack: searching for general relationships. Forest Ecology and Management 22:89-106.

Converse, S. J., W. M. Block, and D. C. White. 2006a. Small mammal population and habitat responses to forest thinning and prescribed fire. Forest Ecology and Management 228:263-273.

Converse, S. J., G. C. White, and W. M. Block. 2006b. Small mammal response to thinning and wildfire in ponderosa pine-dominated forests of the southwestern USA. Journal of Wildlife Management 70(6):1711-1722.

Covert-Bratland, K. A., W. M. Block, and T. Theimer. 2006. Hairy woodpecker winter ecology in ponderosa pine forests representing different ages since wildfire. Journal of Wildlife Management $\mathbf{7 0}$ (5):1379-1392.

Covington, W. W., D. Vosick, and K. A. Lowe. 2005. Southwest fire initiative final report. Submitted to the Bureau of Land Management by the Ecological Restoration Institute, Flagstaff, Arizona, USA.

Dean, J. S. 1988. Dendrochronology and paleoenvironmental reconstruction on the Colorado Plateaus. Pages 119-167 in G.J. Gumerman, editor. The Anasazi in a changing environment. School of American Research Book, Cambridge University Press, New York, New York, USA.

Dodd, N. L., J. S. States, and S. S. Rosenstock. 2003. Tassel-eared squirrel population, habitat condition, and dietary relationships in north-central Arizona. Journal of Wildlife Management 67:622633.

Egan, D. and E. A. Howell, editors. 2001. The historical ecology handbook: a restorationist's guide to reference ecosystems. Island Press, Washington, D.C., USA.

Everett, R. L., R. Schellhaas, D. Keenum, D. Spurbeck, and P. Ohlson. 2000. Fire history in the ponderosa pine/Douglas-fir forests on the east slope of the Washington Cascades. Fire Ecology and Management 129:207-225.

Farris, K. L., M. J. Huss, and S. Zack. 2004. The role of foraging woodpeckers in the decomposition of ponderosa pine snags. The Condor 106:50-59.

Franceschi, V. R., P. Krokene, E. Christiansen, and T. Krekling. 2005. Anatomical and chemical defenses of conifer bark against bark beetles and other pests. The New Phytologist 167:353-376. 
Friederici, P., editor. 2003. Ecological restoration of southwestern ponderosa pine forests. Island Press, Washington, D.C., USA.

Fulé, P. Z., W. W. Covington, H. B. Smith, J. D. Springer, T. A. Heinlein, K. D. Huisinga, and M. M. Moore. 2002. Comparing ecological restoration alternatives at Grand Canyon, Arizona. Forest Ecology and Management 170:19-41.

Fulé, P.Z., W. W. Covington, M. T. Stoddard, and D. Bertolette. 2006. Minimal impact restoration treatments have limited effects on forest structure and fuels at Grand Canyon, USA. Restoration Ecology 14(3):357-368.

Fulé, P. Z., J. Villanueva-Díaz, and M. RamosGómez. 2005. Fire regime in a conservation reserve in Chihuahua, Mexico. Canadian Journal of Forest Research 35:320-330.

Germaine, H. L., and S. S. Germaine. 2002. Forest restoration treatment effects on the nesting success of western bluebirds. Restoration Ecology 10:362367.

Gildar, C. N., P. Z. Fulé, and W. W. Covington. 2004. Plant community variability in ponderosa pine forest has implications for reference conditions. Natural Areas Journal 24(2):101-111.

Grissino-Mayer, H. D., and T. W.Swetnam. 2000. Century-scale climate forcing of fire regimes in the American Southwest. Holocene 10:213-220.

Gunderson, L., and C. S. Holling, editors. 2002. Panarchy: understanding transformations in human and natural systems. Island Press, Washington, D. C, USA.

Gunderson, L., C. S. Holling, and S. Light, editors. 1995. Barriers and bridges to the renewal of ecosystems and institutions. Columbia University Press, New York, New York, USA.

Hart, S. C., A. T. Classen, and R. J. Wright. 2005a. Long-term interval burning alters fine root and mycorrhizal dynamics in a ponderosa pine forest. Journal of Applied Ecology 42:752-761.

Hart, S. C., T. H. DeLuca, G. S. Newman, M. D. MacKenzie, and S. I. Boyle. 2005b. Post-fire vegetative dynamics as drivers of microbial community structure and function in forest soils.
Forest Ecology and Management 220:166-184.

Hoffmeister, D. F. 1986. Mammals of Arizona. University of Arizona Press and Arizona Game and Fish Department, Tucson and Phoenix, Arizona, USA.

Holling, C. S. 1973. Resilience and stability of ecological systems. Annual Review of Ecology and Systematics 4:1-23.

Huckaby, L. S., M. R. Kaufmann, P. J. Fornwalt, J. M. Stoker, and C. Dennis. 2003. Identification and ecology of old ponderosa pine trees in the Colorado Front Range. U.S. Forest Service General Technical Report RMRS-GTR-110.

Kaufmann, M. R., T. T. Veblen, and W. H. Romme. 2006. Historical fire regimes in ponderosa pine forests of the Colorado Front Range, and recommendations for ecological restoration and fuels management. Colorado Forest Restoration Institute, Colorado State University, and The Nature Conservancy, Fort Collins, Colorado, USA.

Keeley, J. E., and N. L. Stephenson. 2000. Restoring natural fire regimes to the Sierra Nevada in an era of global change. Pages 255-265 in D. N. Cole, S. F. McCool, W. T. Borrie, and J. O'Loughlin, compilers. Wilderness science in a time of change conference-Volume 5: Wilderness ecosystems, threats, and management. U.S. Forest Service Proceedings RMRS-P-15-VOL-5.

Korb, J. E., N. C. Johnson, and W. W. Covington. 2003. Arbuscular mycorrhizal propagule densities respond rapidly to ponderosa pine restoration treatments. Journal of Applied Ecology 40:101110.

Kotter, M. M., and R. C. Farentinos. 1984a. Formation of ponderosa pine ectomychorrhizae after inoculation with feces of tassel-eared squirrels. Mycologia 76:758-760.

dispersal agents of hypogeous mycorrhizal fungi. Journal of Mammalogy 65:684-667.

Landres, P. B., P. M. Morgan, and F. J. Swanson. 1999. Overview of the use of natural variability concepts in managing ecological systems. Ecological Applications 9(4):1179-1188. 
Latta, R. G., Y. B. Linhart, D. Fleck, and M. Elliot. 1998. Direct and indirect estimates of seed versus pollen movement within a population of ponderosa pine. Evolution 52:61-67.

Laughlin, D. C., J. D. Bakker, and P.Z. Fulé. 2005. Understory plant community structure in lower montane and subalpine forests, Grand Canyon National Park, USA. Journal of Biogeography 32:2083-2102.

Laughlin, D. C., and J. B. Grace. 2006. A multivariate model of plant species richness in forested systems: old-growth montane forests with a long history of fire. Oikos 114:60-70.

Leopold, A. 1920. Piute forestry vs. forest fire prevention. Southwestern Magazine 2:12-13. (Reprinted as: Paiute forestry. 1990. Pages 139-142 in D.E. Brown and N.B. Carmony, editors. Aldo Leopold's southwest. University of New Mexico Press, Albuquerque, New Mexico, USA.

Long, J. N., and F. W. Smith. 2000. Restructuring the forest: goshawks and the restoration of southwestern ponderosa pine. Journal of Forestry 98:25-30.

MacDonald, L. H., and J. D. Stednick. 2003. Forests and water: a state-of-the-art review for Colorado. Colorado Water Resources Research Institute Report No. 196.

Marcot, B. G. 2002. An ecological functional basis for managing decaying wood for wildlife. Pages 895-910 in W. F. Laudenslayer, Jr., P. J. Shea, B. E. Valentine, C. P. Weatherspoon, and T. E. Lisle, editors. Proceedings of the symposium on the ecology and management of dead wood in western forests. U.S. Forest Service General Technical Report PSW-GTR-181.

Metlen, K. L., and C. E. Fiedler. 2006. Restoration treatment effects on understory of ponderosa pine/ Douglas-fir forests in western Montana. Forest Ecology and Management 222:355-369.

Meyer, M. D., M. P. North, and D. A. Kelt. 2005. Short-term effects of fire and forest thinning on truffle abundance and consumption by Neotamias speciosus in the Sierra Nevada of California. Canadian Journal of Forest Research 35:10611070.
Mooney, K. A., and Y. B. Linhart. 2006. Contrasting cascades: insectivorous birds increase pine but not parasitic mistletoe growth. Journal of Animal Ecology 75:350-357.

Moore, M. M., C. A. Casey, J. D. Bakker, J. D. Springer, P. Z. Fulé, W. W. Covington, and D. C. Laughlin. 2006. Herbaceous vegetation responses (1992-2004) to restoration treatments in a ponderosa pine forest. Rangeland Ecology and Management 59:135-144.

Moore, M. M., W. W. Covington, and P. Z. Fulé. 1999. Reference conditions and ecological restoration: a southwestern ponderosa pine perspective. Ecological Applications 9(4):12661277.

Moore, M. M., D. W. Huffman, P. Z. Fulé, W. W. Covington, and J. E. Crouse. 2004. Comparison of historical and contemporary forest structure and composition of permanent plots in southwestern ponderosa pine forests. Forest Science 50:162-176.

Morgan, T. A., C. E. Fiedler, and C. W. Woodall. 2002. Characteristics of dry site old-growth ponderosa pine in the Bull Mountains of Montana, USA. Natural Areas Journal 22(1):11-19.

Nilsson, C., and G. Grelsson. 1995. The fragility of ecosystems: a review. Journal of Applied Ecology 32: 677-692.

Pattinson, G. S., K. A. Hammill, B. G. Sutton, and P. A. McGee. 1999. Simulated fire reduces the density of arbuscular mycorrhizal fungi at the soil surface. Mycological Research 103(4):491-496.

Reynolds, R. T., T. G. Russel, M. H. Reiser, R. L. Bassett, P. L. Kennedy, D. A. Boyce, Jr., G. Goodwin, R. Smith, and E. L. Fisher. 1992. Management recommendations for the northern goshawk in the southwestern United States. U.S. Forest Service General Technical Report RM-217.

Romme, W. H., D. W. Jamieson, J. S. Redder, G. Bigsby, J. P. Lindsey, D. Kendall, R. Cowen, T. Kreykes, A. W. Spencer, and J. C. Ortega. 1992. Old-growth forests of the San Juan National Forest in southwestern Colorado. Pages 154-165 in M. R. Kaufmann, W. H. Moir, and R. L. Bassett, editors. Old-growth forests in the southwest and Rocky Mountain regions: Proceedings of a workshop. U. 
S. Forest Service General Technical Report RM-213.

Saab, V., L. Bate, J. Lehmkuhl, B. Dickson, S. Story, S. Jentsch, and W. Block. 2006. Changes in downed wood and forest structure after prescribed fire in ponderosa pine forests. U.S. Forest Service Proceedings RMRS-P-41.

Skov, K. R., T. E. Kolb, and K. F. Wallin. 2004. Tree size and drought affect ponderosa pine physiological response to thinning and burning treatments. Forest Science 50(1):81-91.

Smith, J. E., D. McKay, G. Brenner, J. McIvers, and J. W. Spatafora. 2005. Early impacts of forest restoration treatments on the ectomycorrhizal fungal community and fine root biomass in a mixed conifer forest. Journal of Applied Ecology 42:526535 .

Smith, J. E., D. McKay, C. G. Niwa, W. G. Thies, G. Brenner, and J. W. Spatafora. 2004. Short-term effects of seasonal prescribed burning on the ectomycorrhizal fungal community and fine root biomass in ponderosa pine stands in the Blue Mountains of Oregon. Canadian Journal of Forest Research 34:2477-2491.

Snyder, M.A. 1992. Selective herbivory by Abert's squirrel mediated by chemical variability in ponderosa pine. Ecology 73:1730-1741.

1993. Interactions between Abert's squirrel and ponderosa pine: the relationship between selective herbivory and host plant fitness. American Naturalist 141:866-879.

Snyder, M. A., and Y. B. Linhart. 1994. Nest-site selection by Abert's squirrel: chemical characteristics of nest trees. Journal of Mammalogy 75:136-141.

Stephenson, N. L. 1999. Reference conditions for giant sequoia forest restoration: structure, process, and precision. Ecological Applications 9:12531265 .

Swetnam, T. W, C. D. Allen, and J. L. Betancourt. 1999. Applied historical ecology: using the past to manage for the future. Ecological Applications 9 (4):1189-1206.

Szaro, R. C., and R. P. Balda. 1979. Bird community dynamics in a ponderosa pine forest.
Studies in Avian Biology 3.

van Mantgem, P., and M. Schwartz. 2003. Bark heat resistance of small trees in Californian mixed conifer forests: testing some model assumptions. Forest Ecology and Management 178: 341-352.

Veblen, T. T., T. Kitzberger, and J. Donnegan. 2000. Climatic and human influences on fire regimes in ponderosa pine forests in the Colorado Front Range. Ecological Applications 10(4):11781195.

Vireday, C. C. 1982. Mycophagy in tassel-eared squirrels (Sciurus aberti aberti and S. a. kaibabensis) in northern Arizona. Thesis. Northern Arizona University, Flagstaff, Arizona, USA.

Wallin, K. F., T. E. Kolb, K. R. Skov, and M. R. Wagner. 2004. Seven-year results of thinning and burning restoration treatments on old growth ponderosa pines at the Gus Pearson Natural Area. Restoration Ecology 12:239-247.

Ward, J. P., Jr. 2001. Ecological responses by Mexican spotted owls to environmental variation in the Sacramento Mountains, New Mexico. Dissertation. Colorado State University, Fort Collins, Colorado, USA.

Waskiewicz, J.D. 2003. Snags and partial snags in managed, relict, and restored ponderosa pine forests of the Southwest. Thesis. Northern Arizona University, Flagstaff, Arizona, USA .

Youngblood, A., T. Max, and K. Coe. 2004. Stand structure in eastside old-growth ponderosa pine forests of Oregon and northern California. Forest Ecology and Management 228:191-217.

Zausen, G. L, T. E. Kolb, J. D. Bailey, and M. R. Wagner. 2005. Long-term impacts of stand management on ponderosa pine physiology and bark beetle abundance in northern Arizona: a replicated landscape study. Forest Ecology and Management 218:291-305.

Zier, J. L., and W. L. Baker. 2006. A century of vegetation change in the San Juan Mountains, Colorado: an analysis using repeat photography. Forest Ecology and Management 228:251-262. 